RASĀYAN J. Chem.

Vol. 13 | No. 3 |1451-1457| July - September | 2020 ISSN: 0974-1496 | e-ISSN: 0976-0083 | CODEN: RJCABP

\title{
EVALUATION OF LIQUID SMOKE-ACTIVATED PALM KERNEL SHELLS BIOCHAR FOR CADMIUM ADSORPTION
}

\author{
Asri Gani ${ }^{1,2, *}$ and M. Faisal ${ }^{1}$ \\ ${ }^{1}$ Department of Chemical Engineering, Universitas Syiah Kuala, Banda Aceh, 23111, Indonesia \\ ${ }^{2}$ Research Center for Environmental and Natural Resources, Universitas Syiah Kuala, Banda \\ Aceh 23111, Indonesia \\ *E-mail: asri_gani@unsyiah.ac.id
}

\begin{abstract}
This study aims at examining the cadmium metal adsorption using oil palm kernel shell biochar activated with liquid smoke. Charcoal was prepared through the pyrolysis of oil palm shells at a temperature of $380-400^{\circ} \mathrm{C}$. In addition to producing charcoal, this process also produced liquid smoke from the vapor condensed in the condenser unit. Charcoal was crushed using a ball mill and was activated by immersing it in a liquid smoke solution for 24 hours to produce activated carbon, which was then characterized by Fourier Transform-Infrared (FTIR) spectroscopy. The activated carbon was used to adsorb cadmium at various initial concentrations (30 to $150 \mathrm{ppm}$ ), various contact time (from 30 to 180 minutes), and stirring speeds (100 and $150 \mathrm{rpm}$ ). The results show that adsorption efficiency was influenced by contact time and initial concentration. Maximum adsorption efficiency (95\%) was obtained at 180 minutes of contact time and $60 \mathrm{ppm}$ initial concentration. The results of the evaluation of the equilibrium models show that Langmuir isotherm was more suitable (constant correlation $=0.915$ ) to describe cadmium adsorption, with maximum adsorption capacity (qm) and Langmuir constants at $14.8 \mathrm{~g} / \mathrm{mg}$ and $0.131 \mathrm{mg} / \mathrm{g}$ respectively.

Keywords: Liquid Smoke, Palm Kernel Shell, Biochar, Cadmium, Adsorption.
\end{abstract}

(C) RASĀYAN. All rights reserved

\section{INTRODUCTION}

One indicator often used to detect water pollution is heavy metal contamination. A big problem for the environment, heavy metal contamination can be caused by uncontrolled industrial growth, vehicle emissions, agriculture, and domestic activities. Heavy metals are dangerous pollutants because they are toxic, especially when they get into the human body exceeding the tolerable limit. The presence of heavy metals in large quantities will affect various aspects of water, both biologically and ecologically. One of the dangerous heavy metals is cadmium, a metal in the form of silvery-white crystals. Cadmium can be found in industrial alloys, ceramics, soldering wastewater, $\mathrm{Zn}$ purification, pesticides, pigments, textiles and fertilizers. ${ }^{1}$ The human body does not need cadmium to function and grow, as cadmium is very toxic and carcinogenic to humans, animals, and plants ${ }^{2}$ and the World Health Organization has declared that the cadmium threshold in drinking water is $0.003 \mathrm{mg} / \mathrm{L} .^{3}$ Acute poisoning will cause gastrointestinal symptoms and kidney disease. ${ }^{4}$ For this reason, various studies have been carried out to find strategies to remove cadmium from contaminated water.

Many chemical and physical methods have been used to decontaminate metal cadmium from water including coagulation, complexation, electrochemistry, filtration, bioremediation, and adsorption ${ }^{5}$. The adsorption method offers various advantages to remove cadmium metal from waste including its high efficiency, low cost, and flexibility. ${ }^{6,7}$ Various biomass-derived adsorbents such as sunflower seeds ${ }^{8}$, grape seeds ${ }^{9}$, biochar from Ipomoea fistulosa have been used to treat cadmium-contained wastewater.

Before use, generally, adsorbents which are still in the form of charcoal are first activated with such chemical compounds as sodium hydroxide, hydrochloric acid, sulfuric acid, and phosphate compounds so that it becomes activated carbon. Activation is intended to enlarge the adsorbent pores for maximum adsorption. Thus, the activating compound also plays a role in the adsorption process. Among the activator candidates being promoted, liquid smoke can be an option due to its acid content. Liquid smoke

Rasayan J. Chem., 13(3), 1451-1457(2020)

http://dx.doi.org/10.31788/ RJC.2020.1335872

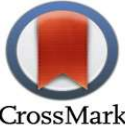


RASĀYAN J. Chem.

Vol. 13 | No. 3 |1451-1457| July - September | 2020

is produced from biomass pyrolysis at $300-400^{\circ} \mathrm{C}$ with little or no oxygen. Today, liquid smoke has been made from various agricultural waste or residues such as oil palm shells, palm fronds, coconut shells and durian skins. ${ }^{10,11}$ Liquid smoke from palm shells has a $\mathrm{pH}$ of around 3 and contains various phenolic acid and carboxylic compounds. ${ }^{12,13}$ Nevertheless, research on the use of liquid smoke as a carbon activator is still very limited that more researches and developments are needed. This study aims to evaluate the ability of the adsorbents from oil palm shell charcoal activated by liquid smoke to adsorb cadmium metal. The efficiency and adsorption capacity of cadmium, isotherm and the adsorption kinetics are then evaluated.

\section{EXPERIMENTAL}

\section{Preparation of Activated Charcoal as an Adsorbent}

Three $\mathrm{kg}$ of oil palm shells were put into a pyrolysis reactor (homemade, stainless steel, diameter $=32 \mathrm{~cm}$, height $=50 \mathrm{~cm}$ ), then heated at a temperature of $300-400^{\circ} \mathrm{C}$ for 3 hours. The vapor coming out of the reactor was condensed into the condensing unit to produce liquid smoke. After the pyrolysis process was completed, the reactor was cooled to room temperature and the resulting charcoal was removed from the reactor and was ground using a ball mill for 24 hours. The liquid smoke obtained was filtered to remove tar impurities. The procedure for preparing the liquid smoke and charcoal follows previous research ${ }^{12,13}$. The activation process was carried out by soaking charcoal in liquid smoke for 24 hours. The activated carbon was then filtered, washed with distilled water to a constant $\mathrm{pH}(6-7)$. The activated carbon was finally dried at $105^{\circ} \mathrm{C}$ for about 12 hours to remove moisture. Then it was cooled in a desiccator at room temperature and put in an airtight container before being used for the adsorption process. The FTIR was used to characterize the activated carbon.

\section{Adsorption Test}

The activated carbon was then used to adsorb cadmium metal obtained from $\mathrm{Cd}\left(\mathrm{NO}_{3}\right)_{2}$ solution. The adsorption process was carried out at various concentrations, namely $30,60,90,120$, and $150 \mathrm{mg} / \mathrm{liter}$. $100 \mathrm{ml}$ of $\mathrm{Cd}\left(\mathrm{NO}_{3}\right)_{2}$ solution was put into a $250 \mathrm{ml}$ Erlenmeyer, into which $1 \mathrm{~g}$ of activated carbon was added, then stirred at the speed of 100 and $150 \mathrm{rpm}$. The contact time between activated carbon and cadmium metal varies in 30,60, 90, 120, 150 and 180 minutes. The filtrate was then separated from the adsorbent by using a centrifuge. Cadmium concentration testing before and after adsorption was carried out using atomic absorption spectroscopy (JEOL-JSM 6510 LA, Shimadzu, Japan).

\section{Characteristics of Adsorbents Using FTIR Test}

\section{RESULTS AND DISCUSSION}

The functional groups found on the surface of activated carbon are strongly influenced by the type of raw material, the type of heating process and the activation process. Oxygen, nitrogen, halogen, and hydrogen are the main elements on the porous surface of activated carbon. These elements can have a significant influence on the surface morphology of activated carbon, the use of adsorbents and ion exchange during the adsorption process. Figure-1(a and b) shows the FTIR spectrum for the adsorbent of pyrolyzed oil palm shells before activation and after being activated using liquid smoke.

The peaks at 3743.83 and $3649.32 \mathrm{~cm}^{-1}$ wavelengths in oil palm shell samples before activation indicate the presence of hydroxyl $(\mathrm{O}-\mathrm{H})$ groups whose presence appears to be reduced in activated carbon samples after chemical activation. This confirms the previous research by $\mathrm{Ma}$, et al. ${ }^{14}$ that identified the presence of $\mathrm{O}-\mathrm{H}$ groups in the pyrolyzed palm oil shells with a wavelength range of $4000-3400 \mathrm{~cm}^{-1}$. The presence of a peak at $3049,46 \mathrm{~cm}^{-1}$ wavelength indicates the presence of a $\mathrm{C}-\mathrm{H}$ group whose intensity also decreases after activation. The reduction of hydrogen bonds after chemical activation was caused using a dehydrated liquid smoke activator. The reduction of $\mathrm{O}-\mathrm{H}$ and $\mathrm{C}-\mathrm{H}$ groups indicates that the activation process removes large amounts of hydrogen and oxygen. Hesas et al ${ }^{15}$ who analyzed pyrolyzed oil palm shells also found the presence of $\mathrm{C}-\mathrm{H}$ groups in the wavelength range of $3000-2850 \mathrm{~cm}^{-1}$. The presence of the $\mathrm{C}-\mathrm{H}$ group has also been identified by Ma, et al. (2016) in the range $3000-2700 \mathrm{~cm}^{-1}$. Aromatic groups in activated carbon samples before activation were observed at peaks with a wavelength of $1575.84 \mathrm{~cm}^{-1}$. The presence of aromatic groups increases upon activation using liquid smoke. It was 
RASĀYAN J. Chem.

Vol. 13 | No. 3 |1451-1457| July - September | 2020

noteworthy that in the activation of liquid smoke, a new peak emerges at a wavelength of $754.17 \mathrm{~cm}^{-1}$, pointing the presence of aromatic groups originating from liquid smoke as an adsorbent activator.

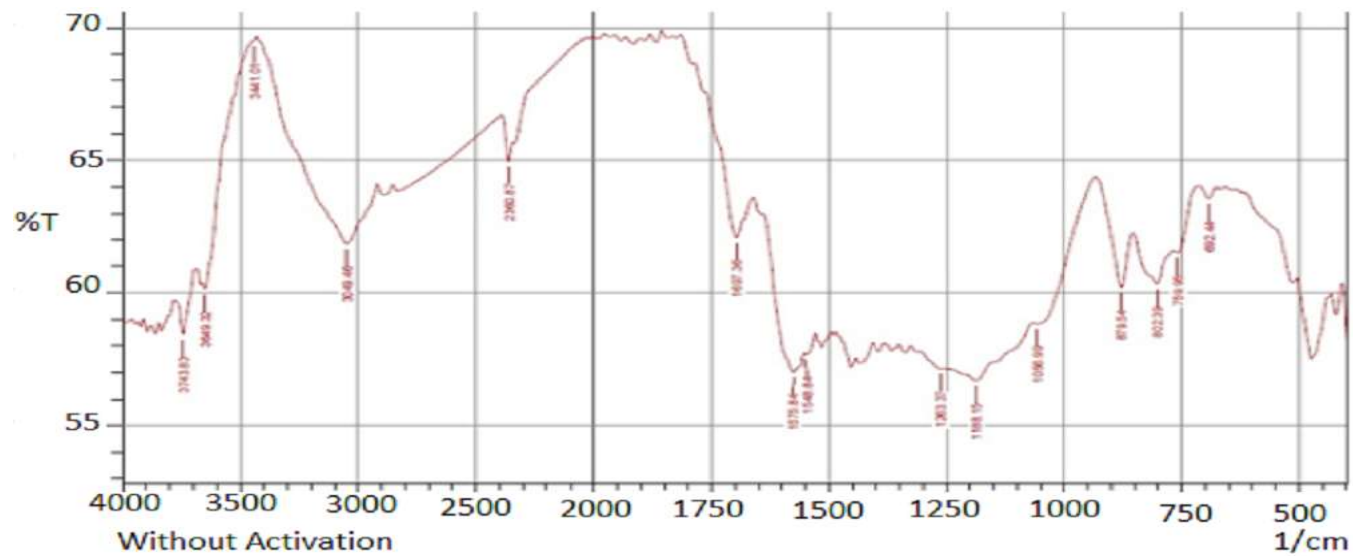

(a)

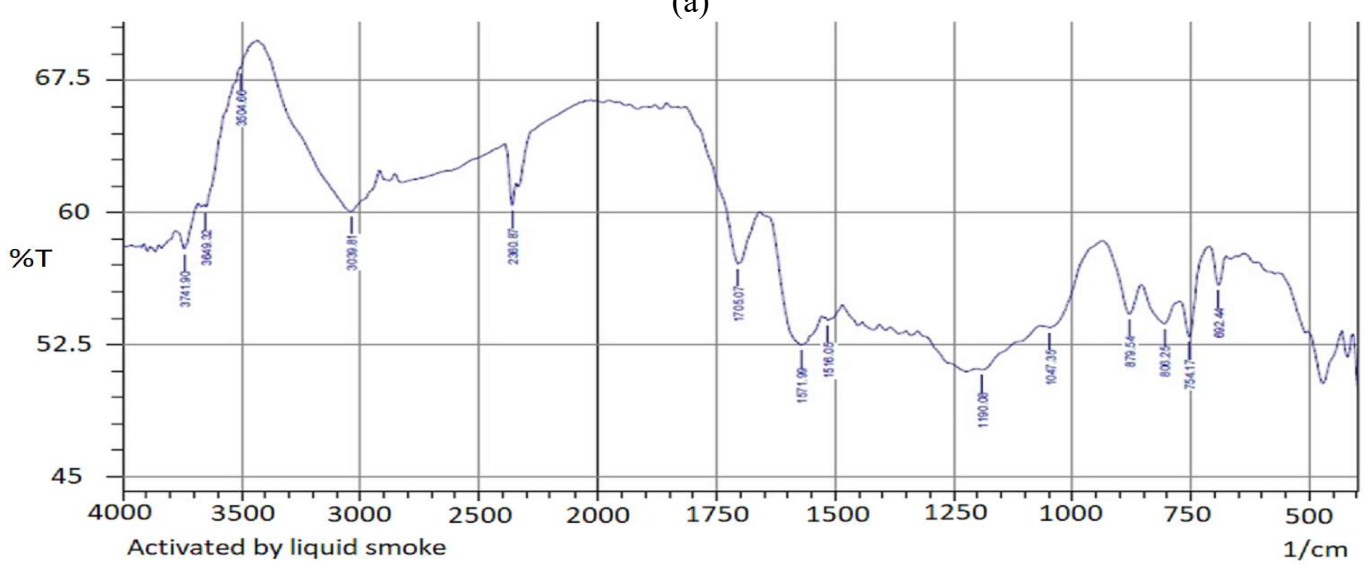

(b)

Fig.-1: FTIR Spectrum for the Adsorbent ( $a=$ without activation, $b=$ activated by liquid smoke)

\section{Study of the Adsorption Process}

\section{Effects of Contact Time and Initial Concentration}

The effect of contact time between adsorbent and cadmium metal ions was studied at various initial concentrations, stirring speeds (100 and $150 \mathrm{rpm})$, and contact time (30-180 min). The effect of contact time on cadmium removal at various initial concentrations is shown in Figures 2 (a-b). For all initial concentrations, cadmium removal increases with increasing contact time between adsorbent and adsorbate. As shown in Figure 2-a, at $100 \mathrm{rpm}$ stirring and $30 \mathrm{ppm}$ initial concentration, removal efficiency increases from $59 \%$ at 30 minutes to $93 \%$ at 180 minutes of contact time. In the contact time range of 60-120 minutes, removal efficiency only increases 3\% from the 30 min contact time, but a sharp increase occurs after 150-minute contact time. The same trend also occurs at an initial concentration of 60 $\mathrm{ppm}$. At the higher initial concentrations $(60-150 \mathrm{ppm})$, removal efficiency at 30 minutes contact time was slightly higher (62-67\%), but it did not change much until 150 minutes of contact time, where removal efficiency ranges at $70 \%$. At 180 minutes of contact time and $90 \mathrm{ppm}$ initial concentration, removal efficiency increases significantly to $94 \%$. This is likely because the contact surface of the adsorbent was still large that it can absorb more cadmium metal. However, at $150 \mathrm{ppm}$ initial concentration, the efficiency drops to $83 \%$, which indicates that at $100 \mathrm{rpm}$ stirring, cadmium metal adsorption was better at low concentrations. It has been reported that at low concentrations, there were more vacant positions of an adsorbent for absorption, thereby increasing concentration slope and increasing cadmium distribution into the adsorbent ${ }^{6}$. 
RASĀYAN J. Chem.

Vol. 13 | No. 3 |1451-1457| July - September | 2020

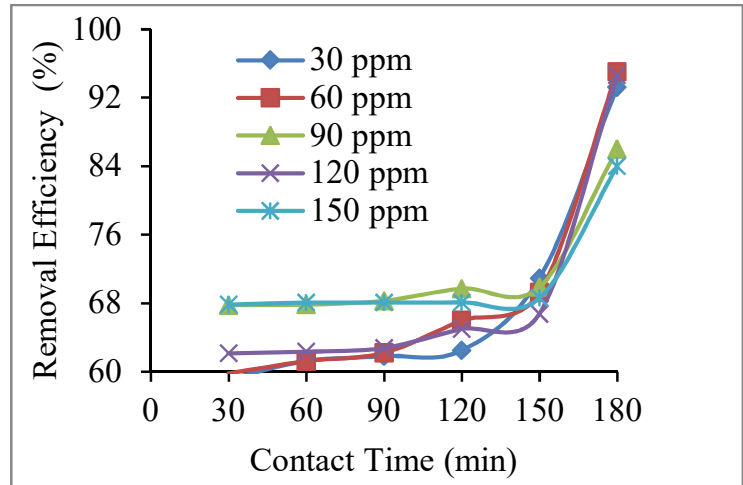

(a)

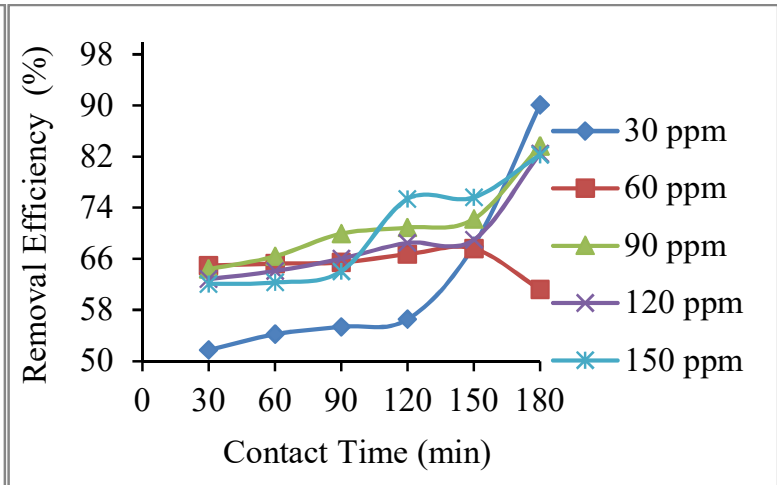

(b)

Fig.-2: Effect of Contact Time on Cadmium Removal Efficiency ( $a=100 \mathrm{rpm}, \mathrm{b}=150 \mathrm{rpm}$ )

Figure- $2 b$ shows the effect of contact time on cadmium removal efficiency at $150 \mathrm{rpm}$. As shown in Fig.$2 \mathrm{~b}$, the tendency for increased removal of efficiency was slightly different from Fig.-2a. Removal efficiency increases slowly until the 180 -minute contact time. At $30 \mathrm{ppm}$ initial concentration and 30,60, $90,120,150$ and 180 minutes of contact time, the removal efficiencies obtained were 51, 54, 55, 56, 68 and $90 \%$ respectively. This value was smaller than that of $100 \mathrm{rpm}$ stirring. Removal efficiency in this study was almost the same as that in the previous studies using palm oil mill sludge biochar (93\%), but using a longer contact time of 240 minutes. The metal removal rate is affected by the mass transfer from the solution to the binding sites. It has been reported that too low stirring prevents the adsorption from taking place thoroughly, whereas too fast stirring prevents a strong bonding between the metal ions and the adsorbent from forming ${ }^{6}$. Stirring facilitates the interaction between the adsorbent and the adsorbate which further increases the diffusion of mass transfer between the cadmium metal and the surface of the activated carbon. However, our results showed that the effect of stirring speed was not significant.

\section{Isotherm Studies}

The adsorption isotherm is a mathematical model that illustrates the interaction between the adsorbate concentration and the adsorbent capacity obtained from the adsorption equilibrium study at a certain temperature. The adsorption isotherm plays a role in determining the maximum conditions to produce optimal adsorption. In this study, the Langmuir and Freundlich models were used to predict the equilibrium distribution of cadmium adsorption in activated carbon biochar from palm oil shells.

\section{Langmuir Isotherm Model}

In the Langmuir model, it is assumed that the monomolecular layer is formed during the adsorption event. All sites are equivalent and there are no interactions between adsorbed species. Adsorption takes place only on specific homogeneous sites in the adsorbent. When a specific site is occupied by an adsorbate molecule, further adsorption will not take place at that site..$^{5,17}$

Table-1: Maximum Adsorption Capacity of Various Adsorbents for Cadmium AQdsorption

\begin{tabular}{c|c|c}
\hline Adsorbent & Maximum Adsorption Capacity (mg/g) & Reference \\
\hline Palm kernel shells (Liquid smoke activated) & 14.81 & Present study \\
\hline Palm kernel shells (NaOH activated) & 22.37 & Ref.6 \\
\hline Bio-nanocomposite of chitosan & 344.00 & Ref. 18 \\
\hline Sugarcane bagasse & 14.80 & Ref.19 \\
\hline $\begin{array}{c}\text { Cocoa pod husk biomass } \\
\begin{array}{c}\text { Microwave induced oil palm shell activated carbon } \\
\text { (phosphoric acid-impregnated) }\end{array}\end{array}$ & 13.43 & Ref.21 \\
\hline $\begin{array}{c}\text { Grape lex activated carbon } \\
\text { Commercial activated carbon (HCL activated) }\end{array}$ & 58.27 .27 & Ref.22 \\
\hline
\end{tabular}


RASĀYAN J. Chem.

Vol. 13 | No. 3 |1451-1457| July - September | 2020

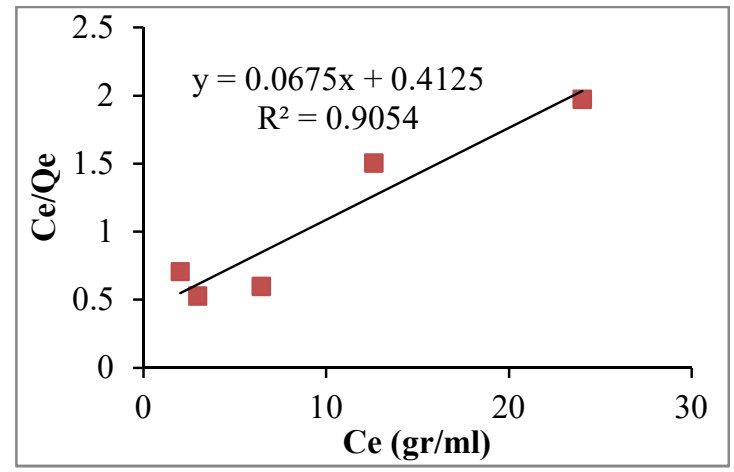

Fig.-3: Langmuir Isotherm Model at $100 \mathrm{rpm}$

Figure-3 shows the equilibrium graph for the Langmuir isotherm model. The intercept shows the adsorption intensity, while the maximum adsorption capacity (qmax) was calculated from the slope. The results of the analysis show that the value of the correlation coefficients $\left(\mathrm{R}^{2}\right)$ for the Langmuir equation was 0.905 . At $100 \mathrm{rpm}$ stirring speed, the values of $\mathrm{qmax}=14.81 \mathrm{~m} / \mathrm{mg}$ and $\mathrm{K}_{\mathrm{L}}=0.16 \mathrm{~L} / \mathrm{g}$ were obtained. This value of the maximum adsorption capacity obtained was lower than in previous studies using activated coconut shell charcoal with $\mathrm{NaOH}$ activator, which was $22.37^{6}$. Table 1 shows qmax from some previous studies.

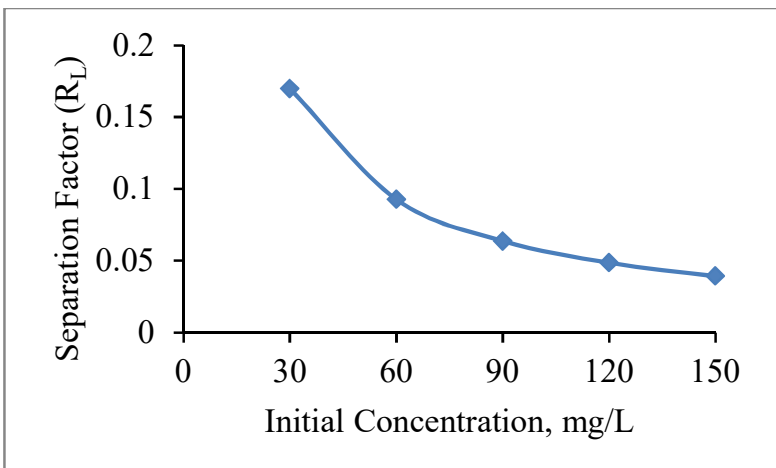

Fig.-4: Relationship between the Separation Factor Constants and Initial Concentration at $100 \mathrm{rpm}$

Important characteristics in the Langmuir isotherm can be expressed in the form of constant separation factor $\left(R_{L}\right)$. This value predicts whether the isotherm takes place irreversibly $\left(R_{L}=0\right)$, favorable $\left(0<R_{L}\right.$ $<1)$ or unfavorable $\left(R_{L}>1\right)$. Figure 4 shows the relationship between the separation factor constants and the initial concentration at $100 \mathrm{rpm}$ stirring. The $\mathrm{R}_{\mathrm{L}}$ value at an initial concentration of $30 \mathrm{mg} / \mathrm{L}$ was 0.169 and decreases to 0.039 at an initial concentration of $150 \mathrm{mg} / \mathrm{L}$. It can be seen that the $\mathrm{R}_{\mathrm{L}}$ value was less than 1 (for all initial concentrations), indicating that the adsorption of cadmium in activated carbon of oil palm shell biochar was favorable.

\section{Freundlich Isotherm Model}

This model describes a heterogeneous system, used to show non-ideal and reversible adsorption forms and not restricts with monolayer formation. This isotherm is widely used to explain the adsorption process of aqueous solutions. The Freundlich isotherm model for cadmium adsorption in this study was presented in Fig.-5. The isotherm constant values $\left(\mathrm{K}_{\mathrm{f}}\right.$ and $\left.\mathrm{n}\right)$ of the Freundlich were 2.779 and 2.009, with $\mathrm{R}^{2}=0.745$. The $\mathrm{R}^{2}$ value of the Freundlich was smaller than Langmuir, which shows that the Langmuir model was more suitable to explain the cadmium adsorption equilibrium system with liquid smokeactivated carbon from palm kernel shells. This indicates that cadmium adsorption was more of monolayer adsorption with minimal interaction between adsorbed ions rather than surface adsorption with heterogeneous energy distribution. ${ }^{21,24}$ The results were different from those in the previous studies using $\mathrm{NaOH}$ activator, whose results show that both isotherm models were compatible. ${ }^{6}$ 
RASĀYAN J. Chem.

Vol. 13 | No. 3 |1451-1457| July - September | 2020

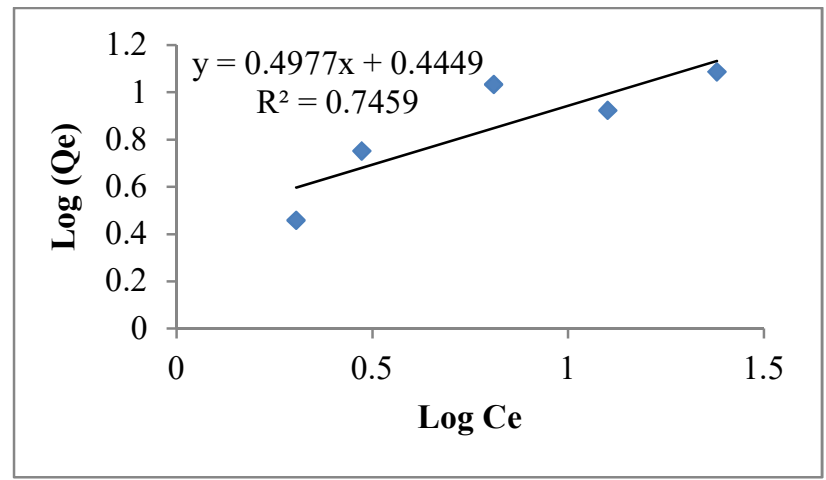

Fig.-5: Freundlich Isotherm Model at $100 \mathrm{rpm}$

\section{CONCLUSION}

In this research, liquid smoke can be an alternative activator to produce activated charcoal from biomass for the adsorption of heavy metals such as cadmium. The maximum adsorption capacity obtained was $14.8 \mathrm{~g} / \mathrm{mg}$ with adsorption efficiency reaching $95 \%$. At the contact time of 30-90 min, adsorption efficiency ranges at $60 \%$ and increases sharply along with the increasing contact time. The Langmuir model was more suitable to describe the isotherms with $\mathrm{R}^{2}=0.9054$, suggesting that monolayer adsorption occurs between adsorbents and cadmium. The kinetics value of the study indicates that the adsorption behavior was better described as the first-order reaction with an $\mathrm{R}^{2}$ greater than 0.99 . At $100 \mathrm{rpm}$ stirring, the values of $K_{1}$ and $Q_{e}$ obtained were $1,045.46 \mathrm{~g} / \mathrm{mg}$.min and $103.09 \mathrm{mg} / \mathrm{g}$ respectively. The value of constant separation factor for cadmium was less than 1 for all initial concentrations and stirring speed, indicating that the cadmium absorption process was going well.

\section{ACKNOWLEDGMENT}

The authors acknowledge Universitas Syiah Kuala for funding and provided research facilities. The authors also thank Sandi and Dodi for their technical support and analyses.

\section{REFERENCES}

1. K. S. Rao, M. Mohapatra, S. Anand, and P. Venkateswarlu, International Journal of Engineering, Science and Technology, 2(7), 81(2010), DOI:10.4314/ijest.v2i7.63747

2. H. Sun, N. Xia, Z. Liu, F. Kong, and S. Wang, Chemosphere, 236, 124370(2019), DOI: 10.1016/j.chemosphere.2019.124370

3. S.S. Pillai, B. Deepa, E. Abraham, N. Girija, P. Geetha, L. Jacob, M. Koshy, Ecotoxicology Environmental Safety, 98, 352(2013), DOI: 10.1016/j.ecoenv.2013.09.003

4. Y.H. Li, S. Wang, Z. Luan, J. Ding, C. Xu, and D. Wu, Carbon, 41(5) 1057 (2003), DOI: 10.1016/S0008-6223(02)00440-2

5. H. Alyasi, H.R. Mackey, K. Loganathan, and G. McKay, Journal of Industrial and Engineering. Chemistry, 81, 153(2020), DOI:10.1016/j.jiec.2019.09.003

6. M. Faisal, A. Gani, and A. Muslim, International Journal of Geomate, 17(64) 252(2019), DOI: $10.21660 / 2019.64 .93855$

7. K. M. Al-Qahtani, Egyptian Journal of Aquatic Research, 43, 269(2017), DOI: 10.1016/j.ejar.2017.10.003

8. M. Jain, V.K. Garg, K. Kadirvelu, and M. Sillanpää, International Journal of Environmental Science and Technology, 13493 (2016), DOI:10.1007/s13762-015-0855-5

9. M. Torab-Mostaedi, M. Asadollahzadeh, A. Hemmati, and A. Khosravi, Journal of the Taiwan Institute of Chemical Engineers, 44, 295(2013), DOI: 10.1016/j.jtice.2012.11.001

10. M. Faisal, A. Gani and F. Mulana, F1000Research, 8, 240(2019), DOI: 10.12688/f1000research.18095.6

11. M. Faisal, A. Gani and Husni, Rasayan Journal of Chemistry, 11(3),1120(2018), DOI: $10.31788 /$ RJC.2018.1132090 
RASĀYAN J. Chem.

Vol. 13 | No. 3 |1451-1457| July - September | 2020

12. M. Faisal, A. Gani, Husni, A. Baihaqi, and H. Daimon, Journal of Engineering and Applied Sciences, 11(12), 2583(2016), DOI:10.36478/jeasci.2016.2583.2587

13. M. Faisal, A. Gani, Husni, and H. Daimon, Internationl Journal of Geomate, 13(37), 116(2017), DOI: $10.21660 / / 2017.37 .2734$

14. Z. Ma, D. Chen, J. Gu, B. Bao, and Q. Zhang, Energy Conversion and Management, 89, 251(2015), DOI: $10.1016 /$ j.enconman.2014.09.074

15. R.H. Hesas, A. Arami-Niya, W.M.A.W. Daud, and J.N. Sahu, Journal of Analytical and Applied Pyrolysis, 104, 176(2013), DOI:10.1016/j.jaap.2013.08.006

16. M.A. Hanif, R. Nadeem, H.N. Bhatti, N.R. Ahmad, and T.M. Ansari, Journal of Hazardous Material, 139(2), 345(2007), DOI:10.1016/j.jhazmat.2006.06.040

17. I. Langmuir, Journal of the American Chemical Society, 40(9), 1361(1918), DOI: $10.1021 / \mathrm{ja} 02242 \mathrm{a} 004$

18. H. Sharififard, E. Rezvanpanah, and S.H. Rad, Bioresource Technology, 270, 562(2018), DOI: 10.1016/j.biortech.2018.09.094

19. U. Garg, M.P. Kaur, G.K. Jawa, D. Sud, and V.K. Garg, Journal of Hazardous Material, 154(1-3), 1149(2008), DOI:10.1016/j.jhazmat.2007.11.040

20. V.O. Njoku, A.A. Ayuk, E.E. Oguzie, and E.N. Ejike, Separation Science Technology, 47(5), 753(2012), DOI:10.1080/01496395.2011.626829

21. I.A.W. Tan, J.C. Chan, B.H. Hameed, and L.L.P. Lim, Journal of Water Process Engineering, 14, 60(2016), DOI:10.1016/j.jwpe.2016.10.007

22. Y. Bian, Z. Bian, J. Zhang, A. Ding, S. Liu, L. Zheng, and H. Wang, Chinese Journal of Chemical Engineering, 23(10) 1705 (2015), DOI:10.1016/j.cjche.2015.08.031

23. F. Sardella, M. Gimenez, C. Navas, C. Morandi, C. Deiana, and K. Sapag, Journal of Environmental Chemical Engineering, 3(1), 253(2015), DOI: 10.1016/j.jece.2014.06.026

24. H. Guo, S. Zhang, Z. Kou, S. Zhai, W. Ma, and Y. Yang, Carbohydrate Polymers, 115, 177(2015), DOI: $10.1016 /$ j.carbpol.2014.08.041

[RJC-5872/2020] 